\title{
EN MENINGSLØS NORSK PERFEKTUM I KONTRAFAKTISKE KONDISJONALSETNINGER
}

\author{
ATLE GRØNN \\ Universitetet i Oslo
}

\section{A B S TRACT}

The paper explores the temporal organization of counterfactual conditionals with focus on the perfect auxiliary ha (= have) in Norwegian. Data from the Oslo Multilingual Corpus suggest that languages like English, German and French are more well-behaved at the syntax-semantics interface when it comes to the use of the (past) perfect in counterfactuals. Indeed, in all Indo-European languages have-/be- in the antecedent of past counterfactuals will typically be semantically empty. However, in Scandinavian the perfect is ambiguous all over the place in counterfactual conditionals. In fact, the temporal auxiliary can optionally be absent in the overt syntax, or it may be overtly expressed but interpreted as identity in the semantics or it can have its expected meaning as a backward shifter. In the latter case, the backward shift can outscope the bare conditional (genuine past counterfactuals) or take local scope inside the antecedent or consequent.

\section{[1] INNLEDNING TIL DET MENINGSLØSE}

Data fra parallellkorpora viser tydelig at skandinavisk/norsk og nederlandsk har et avvikende overforbruk av perfektum i kontrafaktiske kondisjonalsetninger sammenliknet med standardkonstruksjonene i germanske og romanske språk.

Disse problematiske dataene fortjener en liten artikkel eller to selv om jeg er usikker på om det finnes noen fullgod prinsipiell forklaring på denne "misbruken" av perfektum. Om jeg tar feil, utfordrer jeg leseren til å skrive en større og mer prinsipiell artikkel om disse dataene. Slik jeg ser det, er vi nødt til, i et formelt komposisjonelt system, å stipulere en ambiguitet for perfektum, en ambiguitet som for så vidt også er kjent fra antesedenten i språk som engelsk og tysk, eller fransk og italiensk, men som i norsk opptrer temmelig usystematisk over hele linja.

Datagrunnlaget for artikkelen baserer seg utelukkende på Oslo Multilingual Corpus (OMC). Dataene vil ikke bli telt, så min artikkel vil ikke bidra til utbredelsen av ren empirisme, den lingvistiske vekkelsen som har hjemsøkt vårt forskningsfelt de siste årene. Det viktige her er hvilke implikasjoner de autentiske eksemplene har for forholdet mellom form og mening, altså syntaks-semantikkgrensesnittet. 
Kort fortalt må man for norsk stipulere en usystematisk ambiguitet mellom et semantisk reelt og et semantisk tomt hjelpeverb i perfektum-konstruksjonen. Interessant nok kan hjelpeverbet også forbli ikke-uttrykt i syntaksen (Julien 2002), en mulighet som knapt eksisterer utenfor skandinavisk.

Her er noen karakteristiske data der norsk skiller seg ut tilsynelatende uten mål og mening: ${ }^{1}$

(1) (N) Hvis du nå hadde hatt valget mellom Vera og Laura, hvem ville du ha valgt da? - Du mener livet ut?

(E) If you could choose between Vera and Laura now, who would you pick?

(T) Wenn du die Wahl hättest zwischen Vera und Laura, für welche würdest du dich dann entscheiden?

(F) Si tu avais le choix entre Véra et Laura, laquelle choisirais-tu?

Alle indoeuropeiske språk bruker fortidsmorfologi i kontrafaktiske/irreelle kondisjonalsetninger. Dette reiser en rekke interessante lingvistiske spørsmål. Men hvorfor norsk i eksempelet ovenfor bruker pluskvamperfektum i antesedenten og såkalt annen kondisjonalis (ville ha valgt) i konsekventen, er et mer idiosynkratisk spørsmål som naturlig nok ikke er viet særlig oppmerksomhet i litteraturen.

Et tilsvarende avvik mellom norsk på den ene siden og de andre språkene på den andre finner vi også i neste eksempel:

(2) (N) I tillegg til mer enn hundre fortryllede menneskeskikkelser har da også kunstneren plassert nesten like mange andre virveldyr i bildet. Hadde jeg deltatt $\mathrm{i}$ en assosiasjonslek og stikkordet hadde vært "fantasi", ville jeg uten å nøle ha sagt Bosch. Hvis stikkordet hadde vært "Bosch", ville jeg like umiddelbart ha sagt "Lystens hage".

(E) If I was playing at word associations and was given the word "fantasy", I would say Bosch straight away. If the word was "Bosch", I would say "The Garden of Earthly Delights".

(T) Wenn ich bei einem Assoziationsspiel mitmachte und das Stichwort "Fantasie" fiele, dann würde ich sofort "Bosch" sagen. Wäre "Bosch" das Stichwort würde ich den "Garten der Lüste" nennen.

(F) Dans un jeu d'associations d'idées, pour "imagination" je répondrais Le Jardin des délices. A Jardin des délices, j'associerais le mot "misérable".

\section{[2] TEMPORALT PERSPEKTIV I NÅTIDA}

I de to eksemplene ovenfor er det temporale perspektivet til taleren i nåtida. Det ser vi blant annet av tidsadverbialet nå i (1) og presensmorfologien har i venstrekonteksten til (2). I en kontrafaktisk hypotese om nåtida er den forventede

[1] Originalteksten i eksemplene er alltid nevnt først. 
konstruksjonen for norsk - som for andre indo-europeiske språk - den vi møter i (3):

(3) (N) En forutsetningsløs iakttaker fra en annen klode ville ikke spå noe langt liv for menneskeslekten hvis han så oss slik vi står her i dag.

(E) An unprejudiced observer from another planet, looking upon man as he is today, [...] would not prophesy long life for the species.

(T) Sähe man als voraussetzungsloser Beobachter den Menschen, wie er heute dasteht, [...] man würde ihm kein langes Leben voraussagen!

Her har vi konsekvent ett lag med fortidsmorfologi i antesedenten A (så i norsk eller sähe i tysk) og fortidsformen av det modale hjelpeverbet ville/would/würde i konsekventen K. Kondisjonalsetninga er likevel temporalt lokalisert i nåtida ( $i$ dag/today/heute). Vi antar derfor at en semantisk presens har skop over den nakne kondisjonalen i den semantiske strukturen (logisk form, LF) nedenfor:

PRES [[ville [hvis A]] K]

Alle A-verdener nå ${ }_{i}$ er K-verdener nå ${ }_{i}$.

I en prototypisk kontrafaktisk kondisjonal er A-verdenene, der premisset for hypotesen introduseres, mirakelverdener (Lewis 1979). Vår verden (indikativ) er selvsagt ikke blant disse. En vanlig indikativ kondisjonalsetning vil for øvrig ha de samme sannhetsbetingelsene som i parafrasen ovenfor ("Alle A-verdener er K-verdener"). Den eneste, men vesentlige, forskjellen er at indikative kondisjonalsetninger ikke legger noen restriksjoner på hvorvidt vår verden er en A-verden eller ikke. ${ }^{2}$

Fortidsmorfologien i A og K er blitt kalt FAKE i kontrafaktiske kondisjonaler; den er ikke til å stole på og får ikke den forventede temporale fortidsbetydningen på LF. Iatridou (2000) argumenterer for at fortidsmorfologien bidrar med trekket EKSKLUSJON, altså DISTANSE FRA TALESITUASJONEN (Julien 2003). En semantisk operator i tidsdomenet vil gi en tolkning av trekket som preteritum, mens en semantisk operator i verdensdomenet vil gi en irrealis-tolkning. Denne "enten-eller"analysen av fortidsmorfologi er også kjent fra Langacker-inspirerte tempusanalyser i kognitiv grammatikk. Problemet er hvordan man da kan analysere ekte fortidsreferanse i en modal kontekst ("både-og"). Julien (2002) er tydeligvis klar

[2] En fagfelle er ikke helt overbevist om at slike konstruksjoner som i (3) virkelig er kontrafaktiske og ikke bare "hypotetiske". Det refereres her til et tredje nivå på en skala der ekte kontrafaktiske og indikative kondisjonaler er ytterpunktene; hypotetiske kondisjonaler befinner seg midt i mellom og signaliserer at taleren ikke tror at vår verden er med i mengden A-verdener. Uansett hvor reelt dette skillet mellom ekte kontrafaktiske og hypotetiske kondisjonaler måtte være, vil jeg mene at (3) må kunne klassifiseres som en kontrafaktisk konstruksjon. Selv om besøk fra verdensrommet ("fra en annen klode") ikke helt kan utelukkes i FRAMTIDA, har vi ikke erfart noe slikt besøk her og nå ("slik vi står her i dag"). Følgelig har antesedenten en kontrafaktisk tolkning med referanse kun til mirakelverdener. Men se (5) nedenfor for et eksempel som gir en mer "hypotetisk" tolkning. 
over denne tredje muligheten når hun skriver: "skulle can represent only past tense, only counterfactuality (in which case the tense is formally unmarked), or both past tense and counterfactuality."

Jeg har imidlertid ikke sett noen semantiske analyser av denne tredje muligheten, som prinsipielt sett er den eneste gangbare i kontrafaktiske kondisjonaler siden en modal operator alltid må forankres i tid: det som er nødvendig eller mulig på ett tidspunkt, trenger ikke være nødvendig eller mulig på et annet tidspunkt.

Selv om vi befinner oss i mirakelverdener, har derfor proposisjonene i hvissetninga og hovedsetninga like fullt en temporal tolkning. Det ser vi blant annet gjennom bruken av tidsadverbialer som uttrykker referansetida. Vanligvis vil vi også ha samtidighet og en temporal avhengighet mellom de to proposisjonene. Det er derfor viktig at vi har en syntaktisk organisering på LF som gir oss temporal kontroll: nåtidsperspektivet - som kommer eksplisitt til uttrykk gjennom adverbialet $i$ dag i (3) - må inn i både antesedenten og konsekventen. I semantikken oppnås dette gjennom (lambda-)abstraksjon over den øvre referansetida i A og K.

Betydningen til den modale operatoren, i norsk ofte (men ikke alltid) realisert som ville, er nødvendighet, som i en klassisk Lewis-semantikk (Lewis 1979) for kontrafaktiske kondisjonaler: K er nødvendig (gitt A). Et viktig nytt element i LF-skjelettet i (4) sammenliknet med tradisjonelle analyser er den temporale dimensjonen (Grønn \& von Stechow 2011).

Som nevnt en passent ovenfor, er kondisjonaler med enkel fortidsmorfologi ikke rent kontrafaktiske når hypotesen ligger i framtida. Ved teliske predikater må vi anta en kovert framtidsoperator FUT siden hendelsen neppe kan være samtidig med taletidspunktet:

(5) (N) [De] står med ryggen til skrenten og hun forsøker å glemme den, den er som et sug i nakken på henne, hver gang må hun se ned i de dype gatene og bli svimmel. Hvis hun falt ned den skrenten ville hun dø.

(E) If she fell down that precipice she would die.

(T) Wenn sie den Abhang hinabfallen würde, dann müßte sie sterben.

Verbfraser som å falle ned skrenten og å dø er inkompatible med snever nåtidsreferanse og underordnes derfor en kovert operator som skifter referansetida framover. Ved å bruke kontrafaktisk morfologi, altså fortidsmorfologi, i en presenskontekst (står, forsøker, er, må i venstrekonteksten til (5)) signaliserer taleren at hun ikke regner hendelsen $\mathrm{i}$ antesedenten for sannsynlig, men siden kondisjonalen er lokalisert i framtida, kan taleren strengt tatt ikke vite hva som vil skje. Dette ser vi klart i eksempel (6), der taleren eksplisitt åpner for at vår verden kan bli en A-verden (som inkluderer oppfinnelsen av en elektrisk kaptein): 
(6) (N) "Hvis man nå bare kunne oppfinne en elektrisk kaptein også, så ville meget være vunnet," sa Spot, andektig. "Ja De har sannelig rett, De har sannelig rett!" hvinte den gamle, "men tror De det er mulig? En elektrisk kaptein?" "Javisst."

(E) "It would be a great improvement if only they could now invent an electric captain," said Spot solemnly. "Yes, you're right, you're quite right," said the old man. "But do you think that's possible? An electric captain?" "of course."

(T) "Wenn sie jetzt auch noch einen elektrischen Kapitän erfinden, dann wäre viel gewonnen", sagte Spot feierlich. "Ja, Sie haben recht, Sie haben recht", sagte der alte Mann, "aber glauben Sie, daß das möglich ist? Ein elektrischer Kapitän?" "Ja , natürlich."

For Eide (2005) vil dette være eksempler på нүРОтЕтіSкE kondisjonaler.

[3] UTEN 'HA'

I det neste eksempelet - med ateliske predikater - har vi en irrealis hypotese om nåtida, her uttrykt i norsk gjennom en partisipp-for-infinitiv-konstruksjon (ville vert):

(7) (N) Ville hverdagen vært et scoop hvis den til stadighet gikk rundt og gjorde rede for seg?

(E) Would everyday life be a miracle if it went round constantly explaining itself?

(T) Wäre der Alltag eine Sensation, wenn er ununterbrochen Rechenschaft über sich ablegen würde?

(F) Le quotidien serait-il un scoop s'il passait son temps à rendre compte de lui-même?

Fra et indo-europeisk komparativt perspektiv er det overraskende, men fra et semantisk perspektiv gir det en viss mening å utelate det meningsløse hjelpeverbet HA i (7). I de fleste andre germanske språk - inkludert nederlandsk er dette en grammatisk umulighet, men i skandinaviske språk er partisipp-forinfinitiv svært vanlig under modale hjelpeverb (Julien 2002, 2003) og (Eide 2005, 2011). Spørsmålet er hva supinumen vœert kan bety når den opptrer naken uten perfektum-hjelpeverbet.

Mens det er lite litteratur om "misbruken" av perfektum med overt ha i kontrafaktiske kondisjonaler med nåtidsreferanse, er spørsmålet om det manglende hjelpeverbet ha som i ville voert mye diskutert, både i tradisjonelle framstillinger og blant nordiske syntaktikere innenfor et generativt rammeverk. Julien (2002, 2003) og Eide $(2005,2011)$ forsøker å gi disse konstruksjonene en systematisk og 
prinsipiell analyse og tolker den nakne supinum-formen som uttrykk for коNJUNKTIVISK IRREALIS.

De to forfatterne har flere observasjoner som støtter opp om ideen om at det finnes en fornuft bak fraværet av hjelpeverbet $h a$. Såkalt DOBBELSUPINUM kan ikke alltid erstattes av en konstruksjon med ha innfelt mellom de to supinumformene.

(8) Eg hadde ikkje vilja (*ha) gjort det. (Julien 2003, 148)

Julien avviser derfor å postulere et ikke-uttalt ha i slike eksempler. Den alternative konstruksjonen med infinitiv gjera etter modalverbet er heller ikke god ifølge Juliens informanter (9a). Hun diskuterer imidlertid ikke de mest naturlige alternativene og konkurrentene til (8), nemlig (9b-d):

(9) a. ?? Eg hadde ikkje vilja gjera det. (Julien 2003, 148)

b. Eg ville ikkje ha gjort det.

c. Eg ville ikkje gjort det.

d. Eg hadde ikkje gjort det.

Norsk, i motsetning til engelsk, har partisippformer av modale hjelpeverb (nynorsk: vilja under hadde i (8)), men for meg er det uklart om denne konstruksjonen kan uttrykke noe annet enn standardvariantene i ( $9 b-d)$. Som vi vil se senere i del [5], vil hjelpeverbet og fortidsskifteren ha (overt eller kovert) vanligvis ta vidt skop over den modale operatoren på LF, den samme flyttinga som er gjort overt $\mathrm{i}$ syntaksen gjennom hadde vilja i Juliens eksempel. En mulig forklaring på hvorfor noen av Juliens informanter ikke har dobbelsupinum i talemålet sitt, kan være at disse ikke ser noen grunn til å bruke den markerte konstruksjonen i (8) ettersom (8) og (9b) har identiske sannhetsbetingelser.

Det finnes også eksempler fra norske dialekter der supinumen opptrer som et selvstendig ("finitt") verb med irrealis-tolkning, jf. (10a):
a. Fått n se kji kvæmmfølk, så døytt $n$.
(Eide 2011, 10; data fra Hallingdal (Venås 1977))
b. Hadde'n ikke fått seg kvinnfolk, så hadde'n dødd.
(Oslo-dialekt, konstruert).

Dialektdata viser angivelig at supinumen brukt som "finitt" verb ikke kan ha en kontrafaktisk fortidslesning og dermed står i konkurranse med pluskvamperfektumformen: "The pluperfect is used about the past; in this case, the supine form is non-finite and occurs to the right of negation, as the auxiliary is the finite verb [(10b)]. The construction in [(10a)], however, is used to talk about the present and future, and the supine form behaves like a finite verb syntactically, occurring in V1 and V2 positions and to the left of negation" (Eide 2011, 10). 
På bakgrunn av argumentasjonen og observasjonene til Julien og Eide knyttet til dobbelsupinum og supinum som "finitt" verb, vil jeg anta at disse forskerne vil ønske å forklare korpusdataene i denne artikkelen utfra en distribusjon og korrespondanse mellom form og mening som i tabell 1 .

TABELL 1: Forsøk på en prinsipiell form-mening-korrespondanse i kondisjonaler.

\begin{tabular}{|c|c|c|c|}
\hline & NORSK & ENGELSK & FRANSK \\
\hline POTENSIELL NÅTID/FRAMTID & vil være & will be & sera \\
\hline HYPOTETISK NÅTID/FRAMTID & ville være & & \\
\hline KONTRAFAKTISK NÅTID/FRAMTID & ville vært & would be & serait \\
\hline KONTRAFAKTISK FORTID & ville ha vært & would have been & aurait été \\
\hline
\end{tabular}

Ifølge systemet som er tentativt lagt fram i tabell 1, har vi i norsk muligheten til å uttrykke fire ulike kondisjonalsetninger med fire ulike former. I språk som engelsk og fransk vil man derimot ikke skille morfo-syntaktisk mellom hypotetiske og kontrafaktiske betydninger i nåtid/framtid. Jeg vil komme tilbake til denne hypotesen i del [6] og i konklusjonen.

\section{[4] LAG AV TEMPORALE PERSPEKTIVER}

Når vi studerer temporalitet $\mathrm{i}$ autentiske data fra parallellkorpora med hovedsakelig litterære tekster, må vi ofte ta hensyn til fortellerens perspektivtid, som typisk ligger i fortida (før forfatterens tale-/skrivetidspunkt). Dette betyr at en formelt sett dobbel fortidskonstruksjon med (pluskvam)perfektum semantisk sett kan tilsvare en enkel fortidskonstruksjon. I en kontrafaktisk kontekst med falsk fortidsmorfologi, kan vi så stå igjen med en ren presenstolkning (= samtidighet med fortellerens perspektivtid):

(11) (N) Men nå hadde han så vondt at han neppe ville ha reagert hvis noen hadde ropt "Brann! Brann!" engang.

(E) But just now he was in such pain that he would have found it difficult to respond even if someone had burst in and shouted "Fire!"

Tidsadverbialet nå/now gir referansetida som her er et punkt i fortida. I tillegg ser vi at den engelske oversetteren også benytter (pluskvam)perfektum til tross for at referansetida er samtidig med fortellerens perspektiv. Siden hele historien er lagt til fortida, har det ene fortidslaget her sin vanlige temporale betydning.

I språk som norsk og engelsk med fraværende eller fattig konjunktivmorfologi, kan det som på overflaten ser ut som en kontrafaktisk kondisjonalsetning, faktisk være en indikativ presens kondisjonalsetning i en fortidskontekst (fortid fra forfatterens skrivetidspunkt, men samtidighet til fortellerens perspektiv): 
(12) (N) Denne tanken slo ham nå for aller første gang, men han ville aldri kunne få noe svar på spørsmålet. Hvis han gikk hjem nå, ville faren komme ut fra laboratoriet i sin hvite kittel og spørre: "Tilbake allerede?"

(E) If he went home now, his father would come out of his lab in a white smock, possibly holding a plaster cast, and he would ask: "Home so soon?" (T) Wenn er jetzt nach Hause ging, würde der Vater in seinem weißen Kittel aus dem Labor kommen, vielleicht mit einem Gipsgebiß in der Hand, und würde fragen [...]

Eksempel (12) vil i direkte tale/tanke rett og slett være en presens indikativ "hvis han går hjem nå, vil faren komme ut ...".

Mye temporal ambiguitet på dette området skyldes begrensninger i det morfologiske inventaret. Indo-europeiske språk kan vanskelig eksplisitt uttrykke tre lag med fortid, for eksempel et reelt kontrafaktisk fortidsskift i en fortellende fortidskontekst. Man må nøye seg med to lag fortid gjennom (pluskvam)perfektum:

(13) (N) Alt var Wenches feil. Hvis hun ikke hadde gått fra ham, ville livet hans ha artet seg helt annerledes.

(E) If she hadn't deserted him for that creep, things would have been far different.

Dette bringer oss til neste punkt.

[5] FORTIDSPERSPEKTIV

Det kan tenkes at du må lese dette kapitlet både to og tre ganger før du forstår alt sammen.

Jostein Gaarder - eksempel (26)

I enkle kontekster der vi kan se bort ifra komplikasjoner knyttet til forfatterens eller fortellerens perspektivtid - for eksempel i direkte tale - vil kontrafaktiske hypoteser kunne legges med transparente midler til et fortidig tidspunkt før taletida. Germanske og romanske språk må da bruke (pluskvam)perfektum i kombinasjon med det modale hjelpeverbet og eventuelt kondisjonalis/ konjunktivmorfologi. Vi antar at perfektum (i norsk $h a$ ) i hovedsetninga - altså $\mathrm{K}$ - uttrykker et fortidsskift som tar skop over kondisjonalen:

PREs ha [[ville [hvis hadde A]] K]

Det finnes en tid $i$ før nå slik at alle A-verdener da $a_{i}$ er K-verdener da ${ }_{i}$.

Tidspunktet i fortida kan være ubestemt som i parafrasen ovenfor - ha er da en vanlig eksistenskvantor over fortidige tidsintervaller - eller kontekstuelt forankret 
til en bestemt tid. Den bestemte tidsforankringen vil ofte forekomme i kontekster av typen "istedenfor det som faktisk skjedde på et gitt tidspunkt $t$, la oss tenke oss at A skjedde på dette tidspunktet $t$...", jf. (Ogihara 2000) og hans INSTEAD-operator. Som i nåtidskontekstene tidligere beskrevet, kan vi selvsagt ha en temporal forankring uttrykt gjennom eksplisitte temporale adverbialer, for eksempel kadettdagene for 25 år siden og det anaforiske den gang:

(15) (N) Et øyeblikk minnes jeg treningen i formasjonsseiling med jagerne i kadettdagene for 25 år siden. Hvis noen den gang hadde fortalt meg at jeg skulle forsøke noe liknende, men ombord på en fullrigger om et kvart hundre år og på New York havn, ja da ville han blitt diagnostisert som mindre tilregnelig.

(E) If anyone had told me at that time that I would be trying something similar but on board a square-rigger, twenty-five years from then, and in New York Harbor I would have said he was completely crazy.

Som i (7), inneholder eksempel (15) partisipp-for-infinitiv-varianten ville blitt diagnostisert. Denne gangen er det imidlertid klart at vi trenger en reell perfektum, altså annen kondisjonalis ville ha blitt diagnostisert, i hovedsetninga (jf. would have said i den engelske oversettelsen). Dette underminerer ideen bak tabell 1, der ville blitt skulle tilsvare en kontrafaktisk hypotese om nåtida/framtida.

La oss se litt nærmere på syntaks-semantikk-grensesnittet for eksempel (16), som illustrerer to semantisk ekvivalente men syntaktisk ulike konstruksjoner på norsk. Nøkkeldataene er gjentatt i (17).

(16) (N) - Vi ba Dem gjøre rede for Deres forhold til fedrelandet. - Javisst, jeg hørte det, men det er et spørsmål som ikke er lett å utrede. Jeg har grublet over det i mange år, og det har satt meg en god del grå hår i hodet. Men hør nå her: Hvis De hadde spurt meg om min nasjonalitet, da hadde saken vært klar, og jeg ville ikke ha nølt med å svare at jeg er norsk.

(E) But listen: if you had asked me about my nationality the matter would have been dear, and I wouldn't have hesitated to answer that I'm Norwegian.

(T) Aber wissen Sie: Sie mich nach meiner Nationalität gefragt hätten, dann wäre der Fall einfach gewesen, ich hätte ohne zu zögern geantwortet, daß ich Norweger bin.

(F) Alors, écoutez-moi bien: si vous vous étiez enquis de ma nationalité, je n'aurais pas eu l'ombre d'une hésitation et vous aurais tout de suite répondu que j'étais norvégien.

(17) Hvis De hadde spurt ... da hadde saken vært klar (= da ville saken (ha) vært klar / *da saken vært klar). 
(Hvis De hadde spurt) ... ville jeg ikke ha nølt (= ville jeg ikke nølt / hadde jeg ikke nølt)

I én og samme fortidskontekst kan man i norsk ikke bare velge om man vil ha med hjelpeverbet ha, men man kan også fritt veksle mellom en overt ville-operator og en kovert VILLE-operator. Tilstedeværelsen på LF av en kovert kontrafaktisk nødvendighetsoperator er karakteristisk for mange språk, som for eksempel tysk og russisk. ${ }^{3}$ Legg merke til at når man utelater ville, kan man ikke i standard norsk bokmål eller nynorsk sløyfe $h a$-hjelpeverbet fra hovedsetninga siden hadde opptrer i en finitt form.

Nedenfor følger vår morfo-syntaktiske og semantiske analyse av de to konstruksjonene i (17). Vi starter med den første konstruksjonen der vi har en overt kontrafaktisk modal ville. ${ }^{4}$

$\mathrm{N} \lambda_{0} \operatorname{IRR}\left(t_{0}\right) \lambda_{1} \operatorname{ha}\left(t_{1}\right) \lambda_{2} \operatorname{ville}\left(t_{2}\right)\left[\lambda_{3}\right.$ hvis hadde $\left.\left(t_{3}\right) \lambda_{4} \operatorname{spurt}\left(t_{4}\right)\right]\left[\lambda_{5} \operatorname{ikke} \operatorname{nølt}\left(t_{5}\right)\right]$ in ip,is un up,us up,us up,us

FIGUR 1: Kontrafaktisk fortidskonstruksjon med overt ville.

Hvorfor trenger vi en abstrakt irrealis-operator IRR i figur 1, kunne ikke operatoren ville sjekke verbmorfologien til de andre verbene i sitt semantiske domene?

Svaret på det siste spørsmålet er nei, og det er minst to grunner til dette. For det første, hvis ville/would var irrealis/konjunktiv-operatoren i setninga, kunne vi ikke forklare hvorfor ville/would ikke kan opptre isolert i matrisesetninger:

(18) Mens det regnet klokka 3, sa Ola: "Sola vil skinne klokka 5." Men Ola tok feil. Det regnet fremdeles klokka 5.

$\Rightarrow$ Ola sa klokka 3 at sola ville skinne klokka 5 .

(19) Klokka 3 regnet det. (\#) Sola ville skinne klokka 5. Det regnet fremdeles klokka 5.

Vi ser at det modale hjelpeverbet ville/would kan brukes under et proposisjonalt ytringsverb (eller eventuelt i fri indirekte tale), men det skyldes nettopp at slike verb (her: sa) skaper en intensjonal kontekst, og dermed kan kombineres med konjunktiv i for eksempel tysk (det samme gjelder fri indirekte tale). Konklusjonen er at ville/would krever en høyerestående intensjonal operator, som for

[3] Det er problematisk å analysere modalverbet würde i tysk som et direkte motstykke til den overte formen ville/would siden würde ofte opptrer både i A og K. Det samme gjelder konjunktivpartikkelen by i russisk. $\mathrm{Vi}$ antar derfor at tysk og russisk har en kovert nødvendighetsoperator i kondisjonalsetninga.

[4] Jeg opererer her med et forenklet system der verb og temporale/modale operatorer har et temporalt argument. N er taltetidspunktet ("nå"), mens lambdaene brukes til å abstrahere over det temporale argumentet. I lisensieringen av morfo-syntaksen står prefikset i for et tolkbart trekk ("interpretable"), mens u er et ikke-tolkbart trekk; n er "now", p er "past", mens s er "subjunctive". 
eksempel en abstrakt IRR. I språk som tysk eller italiensk med mye konjunktivmorfologi i kontrafaktiske kondisjonaler vil IRR sjekke/lisensiere denne morfologien i sitt semantiske domene. Det samme gjelder for lisensieringen av verbformen were i engelsk (if I were ...).

Den andre grunnen til at vi trenger en abstrakt IRR, vil vi se når vi går gjennom analysen av neste eksempel. Men la oss først gå tilbake til figuren ovenfor.

Alle verb og tidssensitive operatorer har et temporalt argument. Når det temporal argumentet abstraheres over ( $\lambda$-abstraksjon), får vi muligheten til å kontrollere argumentet gjennom semantisk binding fra en høyerestående operator. I den første konstruksjonen har vi en semantisk fortidsoperator, nemlig hjelpeverbet (tilbakeskifteren) ha som gir den temporale tolkningen til A og K..$^{5}$ Operatoren IRR er semantisk tom - den modale nødvendigheten uttrykkes leksikalsk gjennom ville - men kommer med to tolkbare trekk: ip ("interpretable past") og is ("interpretable subjunctive"). Videre ser vi at IRR er forankret til nåtida $\mathrm{N}$ (talerens ytringstid). Prinsippene for lambdakalkyle og en standard tidsrelasjonell semantikk for HA vil i sin tur føre til at $\mathrm{N}$ blir det eksterne temporale argumentet for HA (det finnes en tid $t_{1}$ før $\mathrm{N}$ ). Dette fortidsintervallet $t_{1}$ vil videre bindes inn som argument for nødvendighetsoperatoren ville. Nødvendighetsrelasjonen mellom antesedenten og konsekventen er altså lokalisert i fortida, på intervallet $t_{1}$. Siden setninga ikke inneholder flere temporale operatorer, vil både spørre-hendelsen i antesedenten og den negerte nølingen i konsekventen finne sted på $t_{1}$.

For å oppnå den korrekte temporale konfigurasjonen må altså ha fra hovedsetninga ha skop over ville. Men hvordan kan vi forklare de morfo-syntaktiske trekkene? Her spiller IRR en avgjørende rolle. De temporale variablene i domenet til IRR vil under semantisk binding arve de ikke-tolkbare trekkene up ("uninterpretable past") og us ("uninterpretable subjunctive"). For infinitte verbformer infinitiven ha og de to partisippene spurt og vort - vil de ikke-tolkbare trekkene kunne ignoreres da supinumformene ikke har morfologisk tempus ${ }^{6}$. For modalverbet ville har vi derimot en lisensiering fra IRR. I norsk, som mangler konjunktivmorfologi, vil trekk-kombinasjonen up og us realiseres som ren fortidsmorfologi (men ikke med fortidsbetydning!). Fortidsbetydningen kommer ene og alene fra hjelpeverbet ha i hovedsetninga. Men dette betyr at hadde i antesedenten ikke spiller noen rolle som tidsoperator. Semantisk sett er hadde tom, men morfolo-

[5] For konstruksjonen uten et overt ha - det vil si varianten ville jeg ikke nølt - måtte vi her ha stipulert en kovert tilbakeskifter PAST/HA med samme semantikk som ha. Jeg antar derfor at ville jeg ikke nølt $\mathrm{i}$ dette tilfellet nødvendigvis oppstår gjennom ha-stryking, en observasjon som ble gjort allerede av Aasen (1864).

[6] I motsetning til Julien $(2002,2003)$ og Eide $(2005,2011)$ regner jeg ikke supinumformen som bærer av morfologisk tempus eller konjunktiv i norsk, men det formelle systemet åpner for denne muligheten. Supinumformene befinner seg i det semantiske domenet til IRR og kan derfor arve trekket us ("uninterpretable subjunctive") om ønskelig. Supinum vil også alltid befinne seg i domenet til en høyere tidsoperator. 
gisk gjør hjelpeverbet ingen skade siden trekkene up,us (arvet fra IRR gjennom semantisk binding) korrekt realiseres som morfologisk fortid: -dde.

En fullstendig analyse av disse konstruksjonene krever en mulige-verdenersemantikk (samt aspekt- og eventsemantikk), noe som ikke er utbokstavert her. Sannhetsbetingelsene for vår første eksempelsetning i (17) kan da parafraseres noe forenklet:

(20) Alle alternative situasjoner den gang $\mathrm{da}_{i}$ før nå, slik at De spør meg da $\mathrm{da}_{i}$, er situasjoner der jeg ikke nøler da $\mathrm{da}_{i}$.

La oss nå se på den viktige alternative konstruksjonen som vi også finner i (17):

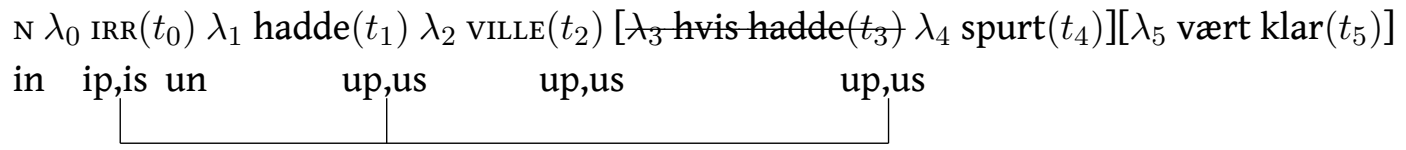

FIGUR 2: Kontrafaktisk fortidskonstruksjon med kovert VILLE.

Forskjellen mellom de to setningene i (17) er at VILLE i siste setning er kovert, mens den temporale tilbakeskifteren HA denne gang har morfologiske trekk: hadde. Siden hadde må ha skop over viLLE, ser vi hvorfor lisensieringen av morfologiske trekk krever en abstrakt operator IRR. Uten IRR ville vi ikke kunne forklare den falske (konjunktiviske) fortidsmorfologien til hadde. Hele kondisjonalen inneholder to finitte verb - to forekomster av hadde - som begge får sin morfologi sjekket i en kongruensrelasjon med IRR. Som ovenfor må vi stipulere at hadde i A er semantisk tomt.

Med denne analysen kan vi forklare morfo-syntaksen i de to konstruksjonene samtidig som vi ender opp med en korrekt semantikk som forteller oss at sannhetsbetingelsene er identiske for variantene med og uten en overt ville.

Det er verdt å nevne at hvis ikke er en meningsbærende operator, men semantisk tom i vår analyse. Slik har det vært i den semantiske litteraturen siden Kratzers innflytelsesrike arbeider fra slutten av 1970-tallet, oppsummert i (Kratzer 2012). Antesedenten er for øvrig strengt tatt ikke et argument til ville, men kommer inn via en egen komposisjonsregel for modal modifisering (Grønn \& von Stechow 2011). I eksempel (17) ovenfor er antesedenten elliptisk i den andre kondisjonalen. I eksemplene nedenfor er subjunksjonen hvis/if/wenn/esli utelatt i norsk, engelsk, tysk og russisk men uttrykt i fransk (si) uten at tolkningen påvirkes:

(21) （N) Hadde ikke Jacob vært så vakker, ville han nok ha vakt avsky både hos hjemmefolk og fremmede.

(E) People both at home and abroad would surely have found Jacob disgusting had he not been such a handsome man.

(T) Hätte Jacob nicht so gut ausgesehen, dann hätte er wohl zu Hause und 
bei Fremden Abscheu erregt.

(R) Ne bud' Iakov tak krasiv, on vyzyval by k sebe otvrashchenie i u domashnikh, i u postoronnikh.

(F) Si Jacob n'avait pas été aussi beau, il aurait probablement éveillé le dégoût chez tout le monde.

\section{[6] EN MENINGSFULL PERFEKTUM}

Kompleksiteten i dataene fra parallellkorpora kan gi interessante utslag i oversettelsene. I (22) inneholder den norske originalsetninga på ny en partisipp-forinfinitiv - ville stirret - som den engelske oversetteren tolker som would stare. Her er det imidlertid mye som tyder på at would have stared er påkrevd:

(N) ARVID: Min morfar ville sikkert stirret uforstående på meg hvis jeg hadde fortalt ham om det viktigste som skjer i norske fiskerier i dag, om det som kalles aquakultur, fiskekultur eller fjord-farming.

(E) ARVID: My grandfather would undoubtedly stare at me in bewilderment if I had told him that the most important happenings in the Norwegian fishing industry today were aquaculture, fish-culture or fjordfarming.

Bruken av pluskvamperfektum i A hvis jeg hadde fortalt gir en første pekepinn om at ville stirret i denne konteksten er en variant av ville ha stirret, altså en kontrafaktisk konstruksjon forankret i fortida. I dette konkrete tilfellet blir forskjellen på originalteksten og oversettelsen ganske stor, et spørsmål om liv og død.

Den engelske oversettelsen plasserer hypotesen i nåtida med et lokalt tilbakeskift i A (tell_him $\prec$ stare_at_me), men det forutsetter at morfaren, som det snakkes om, er i live i de alternative verdenene til vår verden her og nå. Hvis fortelleren Arvid derimot snakker om sin døde morfar, er han nødt til å plassere hele irrealishypotesen i fortida. Hvis ikke, får vi et brudd på presupposisjonsbetingelsene for kontrafaktiske kondisjonaler, jf. (Ippolito 2003). Hvis vi følger standardanalysen i (Lewis 1979), kan vi si at de alternative mirakelverdenene skal være maksimalt like vår verden, men i vår verden er morfar $\mathrm{d} ø \mathrm{~d}$, og Arvid kan derfor ikke fortelle ham noe, og morfar kan heller ikke stirre på Arvid.

Et annet eksempel på forvirring har vi i (23), der den norske originalen - som er fullt akseptabel - kan by på utfordringer for oversetterne:

(23) (N) Hun [...] hører ungeskrålet fra de åpne nedtråkkede gressbakkene mellom blokkene, ser bilene som står parkert, klesvasken på stativene, sandkassene og syklene og vinduer som blinker hvitt i ettermiddagssolen. Hvis de bodde i rekkehus eller enebolig ville kanskje mye vært anderledes. (E) If they lived in a terraced house or a detached house, then perhaps many things would have been different. 
(T) Wenn sie in einem Reihenhaus oder Einfamilienhaus wohnen würden, wäre vielleicht vieles anders.

Den engelske og tyske oversetteren har valgt to ulike løsninger. Den engelske oversetteren har her tolket partisipp-for-infinitiv-konstruksjonen ville mye voert anderledes som annen kondisjonalis: ville mye ha vort anderledes. Siden antesedenten har enkel fortid, betyr dette muligens at oversetteren til engelsk har intendert en lokal tilbakeskifter i konsekventen (ikke med skop over hele kondisjonalen). ${ }^{7}$

Jeg vil tro at dette ikke er den intenderte meningen på norsk. I denne konteksten er det mer naturlig å tolke ville mye voert anderledes som et kontrafaktisk utsagn knyttet til nåtida. Dette har den tyske oversetteren forstått. Forfatteren (Bjørg Vik) er nok på linje med de fleste norsktalende når hun bruker partisippfor-infinitiv framfor alternativet ville mye vore anderledes. ${ }^{8}$

I det neste eksempelet (24), derimot, er det logisk med et lokalt temporalt tilbakeskift i konsekventen (både i engelsk og norsk):

(E) For if species identification was the function of the stripes they would have diverged much more in the three cases. If it was important for an individual animal to be able to distinguish between other zebras, evolution would have led the three patterns away from one another to a greater degree.

(N) For hvis hensikten med stripene var artsidentifikasjon, ville de ha vært mye mer forskjellige hos de tre artene. Hvis det var viktig for et enkelt dyr å kunne skjelne mellom artene, ville evolusjonen ha sørget for at forskjellen mellom de tre mønstrene var blitt større.

Hvis det NÅ var viktig å kunne skjelne artene, ville evolusjonen TIDLIGERE - altså før nå - ha sørget for at forskjellene var blitt større. En LF vil dermed se slik ut, noe som viser at dette er en presenskondisjonal med en temporal tilbaketrekning i K:

[7] Teknisk sett er det mulig at den engelske konstruksjonen er forankret i fortida og at have i konsekventen har vid rekkevidde. Dette skyldes at den manglende had i antesedenten uansett måtte ha blitt strøket på LF om den hadde blitt uttrykt i syntaksen. Imidlertid er det ikke vanlig i germanske og romanske språk å ha enkel fortidsmorfologi i A ved kontrafaktiske fortidskondisjonaler med perfektum i matriks K. Hvorfor denne økonomiske og komposisjonelt velfungerende kombinasjonen ikke forekommer oftere, er en gåte.

[8] For Eide $(2005,2011)$ og Julien $(2002,2003)$ er ville vert og ville vœre ikke helt ekvivalente, jf. hypotesen i tabell 1. Mine informanter godtar begge variantene uten noen klar betydningsforskjell, men sier at de selv ville ha valgt enten ville voert eller ville ha vort i muntlig språk. I andre eksempler forankret i nåtida, som (3) med ville spå eller (7) med ville vcert, synes infinitiven eller partisipp-for-infinitiv å kunne brukes om hverandre, men sistnevnte forekommer nok hyppigst i moderne talespråk i konkurranse med ville $h a+$ partisipp. 
(25) PRES IRR [[ville [hvis A]] ha K]

Alle A-verdener nå ${ }_{i}$ er K-verdener nå ${ }_{i}$ med en K-hendelse på et tidspunkt $i^{\prime}$ før nå $_{i}$.

Et lokalt skifte av referansetida bakover vil nok oftere skje i antesedenten, som i den norske originalen og tyske oversettelsen nedenfor:

(26) (N) Det kan tenkes at du må lese dette kapitlet både to og tre ganger før du forstår alt sammen. Men forståelse må koste litt egeninnsats. Du ville neppe beundre en venninne som forstod seg på både det ene og det andre hvis det ikke hadde kostet henne noe.

(E) You probably wouldn't admire a friend who was good at everything if it cost her no effort.

(T) Du würdest eine Freundin, die alles mögliche kann, wohl kaum bewundern, wenn diese Fähigkeiten sie nicht etwas gekostet hätten.

(27) PRES IRr [[ville [hvis hadde A]] K]

Alle A-verdener nå ${ }_{i} \operatorname{der} \operatorname{det}$ ikke finnes en tid $i^{\prime}$ før nå ${ }_{i}$ slik at din venninne har gjort seg flid på $i^{\prime}$, er K-verdener nå ${ }_{i}$ der du neppe beundrer venninnen nå ${ }_{i}$.

I det neste eksempelet er den norske originalen igjen en smule forvirrende, men her har oversetterne gjort en god jobb. Både den engelske og tyske oversettelsen viser at vi har en lokal tilbakeskifter i A, mens hele kondisjonalen er underlagt PRES:

(28) (N) Sofie ble gående omkring i den store hagen. Hun prøvde å glemme alt hun hadde lært på skolen. Spesielt viktig var det å glemme det hun hadde lest i naturfagbøkene. Hvis hun hadde vokst opp i denne hagen uten å vite noe som helst om naturen, hvordan ville hun opplevd våren da?

(E) If she had grown up in this garden without knowing anything at all about nature, how would she feel about the spring?

(T) Wenn sie in diesem Garten aufgewachsen wäre, ohne sonst irgend etwas über die Natur zu wissen, wie würde sie dann den Frühling erleben?

Det samme mønsteret, der partisipp-for-infinitiv ville ikke visst i $\mathrm{K}$ tilsvarer ville ikke vite med en lokal hadde i A, finner vi i (29):

(29) (N) Hvis ikke Platon hadde skrevet, ville vi ikke visst stort om Sokrates. Hvis han ikke hadde skrevet om Sokrates, ville vi ikke visst noe om Platon.

(E) If Plato had not written, we would not know much of Socrates. If he had not written of Socrates, we would not know of Plato.

(T) Wenn Platon nichts geschrieben hätte, wüßten wir wenig von Sokrates. 
Wenn er nicht über Sokrates geschrieben hätte, wüßten wir nichts über Platon.

(Ne) Als Plato niet had geschreven zouden wij niet veel over Socrates hebben geweten. Als hij niet over Socrates had geschreven zouden wij niets over Plato hebben geweten.

Igjen har den engelske og tyske oversetteren klart å sette skapet på plass, mens den nederlandske oversetteren gjør tolkningen lite transparent med pluskvamperfektum både i A og K. Nederlandsk, i motsetning til norsk, har ikke mulighet til å sløyfe det tomme (eller ikke-tomme) hjelpeverbet i K.

La oss ta med et par eksempler som viser noen begrensninger også i språk som engelsk og tysk. Morfologien i overflatesyntaksen gir oss her en kontrafaktisk kondisjonal forankret i fortida. Tolkningen krever imidlertid ytterligere en lokal fortidsskifter i antesedenten:

(30) (E) Rawlings knew it would have been easier for all if a route for the Glen suite had been set up before the robbery.

(N) Rawlings visste det ville vært lettere for alle parter hvis det hadde vært lagt en rute for Glen-settet før tyveriet.

(T) Rawlings wußte, daß es für alle Beteiligten leichter wäre, wenn man schon vor dem Diebstahl einen Absatzweg für die Glen-Diamanten ausfindig gemacht hätte.

Vi kan løse dette problemet ved å anta at vi i (30) unntaksvis ikke har en semantisk tom PERF i A. Vi har altså to semantiske perfektum-operatorer i disse setningene. Hovedsetningas PERF gir oss den fortidige forankringen for hele kondisjonalen, mens bisetningas PERF har en lokal tolkning.

I det neste eksempelet ønsker den norske oversetteren å tvinge fram en lokal tolkning av hadde i A. Dette gjøres ved å legge inn tilbakeskift-partikkelen allerede . Løsningen er interessant, men ikke nødvendigvis riktig da sannhetsbetingelsene ikke lenger er identiske med den engelske originalsetninga, som har en tvetydig perfektum i A (datoangivelsen i A kan referere til hendelsen eller en referansetid etter hendelsen):

(31) (E) Although the inability of the Canadians to fulfil Montgomery's proclaimed intention was an embarrassment to him, there is every reason to suppose that if the Allies had blocked the eastward escape of the German army with a north-south cordon around 15 August, the Germans would have smashed through it.

(N) Selv om Montgomery var ille berørt av kanadiernes manglende evne til å gjennomføre det opplegget han hadde tenkt seg, er det all grunn til å anta at hvis de allerede hadde blokkert den tyske hærens østlige fluktrute 
med en nord-sør-linje omkring den 15. august, ville tyskerne ha slått seg gjennom den.

La oss et øyeblikk vende tilbake til diskusjonen i del [3] om utelatelsen av hjelpeverbet ha. Vi har nå sett eksempler som (15) og (22), der vi har syntaktisk hastryking i en kontrafaktisk fortidskontekst, jf. (Aasen 1864). Denne konstruksjonen virker helt kurant i norsk skrift og tale, men strider mot hypotesen i tabell 1. Samtidig kan den spesielle skandinaviske partisipp-for-infinitiv-konstruksjonen også brukes i kontrafaktiske hypoteser i nåtida/framtida. De to ulike tidsforankringene for partisipp-for-infinitiv gjør det dessverre vanskelig å gi en komposisjonelt tilfredsstillende, eller i det minste prinsipiell, analyse av mine korpusdata slik Julien $(2002,2003)$ og Eide (2011) tar til orde for i andre supinum-konstruksjoner uten $h a$. Det ser ikke ut til å være noen elegant systematikk i utelatelsen av ha i kontrafaktiske kondisjonalsetninger. Fraværet i syntaksen forekommer ikke systematisk og kan derfor ikke tillegges noen spesiell semantisk motivasjon. I (15) og (22) må ha-strykingen dessuten reverseres på LF gjennom å sette inn en kovert operator HA.

\section{[7] PAST PERFECT FUTURE TENSE}

I en av de inderligste tempusanalyser som er gjort av noen nordmann, lanserte Aha-musikeren Magne Furuholmen konstruksjonen Past Perfect Future Tense i selve tittelen på sitt første soloalbum fra 2004 på plateselskapet Passionfruit. I den mer semantisk skolerte litteraturen ble denne kombinasjonen tatt på alvor ett år tidligere av Ippolito (2003). Men Ippolito-setningene var oppkonstruerte og derfor ikke alltid helt overbevisende for alle lesere. Her kommer parallellkorpuset oss til unnsetning:

(32) (T) Wenn ich heute den großen Büffel getötet hätte - und mein Pfeil lag schon auf der Sehne, als man mich rief -, dann wäre ich morgen ein Jäger gewesen.

(N) Hadde jeg drept den store bøffelen i dag - ja, pila mi lå allerede mot buestrengen, da de ropte på meg - så hadde jeg vært jeger i morgen.

(E) If I had killed the big buffalo today - and my arrow was already fitted to my bowstring - I'd have been a hunter tomorrow.

Dette er en virkelig lekkerbisken med eksplisitte temporale adverbialer som angir referansetida både i A (tidligere) $i$ dag og $\mathrm{K}$ i morgen. Det er altså ingen tvil om den temporale konfigurasjonen. Morfologien tvinger oss til å bruke pluskvamperfektum over hele linja i alle språkene, også i mer forutsigbare språk som engelsk og tysk, men semantisk sett har vi et temporalt framoverskift lokalt i hovedsetninga. 
PRES IRR hadde [[VILLE [hadde A]] FUT K]

Det finnes en tid $i$ tidligere i dag før nå slik at alle verdener der jeg dreper bøffelen på $i$ er verdener som utvikler seg slik at jeg er jeger på en tid $i^{\prime}$ dagen etter $i /$ nå.

Av den skisserte analysen ovenfor ser vi at rammeverket vårt er fleksibelt nok til å fange opp semantikken til denne konstruksjonen. Morfologien blir lisensiert på vanlig måte siden den lokale FUT-operatoren er kovert og kommer uten tolkbare trekk.

\section{[8] EN MENINGSLØS KONKLUSJON}

Vi har tatt den temporale organiseringen i norske kontrafaktiske kondisjonaler på alvor. Samtidig har vi skissert en analyse som gjelder mer generelt for disse konstruksjonene i indo-europeiske språk, her med innslag av parallelle data fra engelsk, tysk, fransk, nederlandsk og russisk.

Dataene og analysen viser at den leksikalsk uttrykte ha-operatoren i norsk kan være både meningsløs og meningsbærende. I en komposisjonell teori er det enklest å si at en meningsløs operator uttrykker IDENTITET (input og output er det samme). Vi får da følgende ambiguitet for perfektum-hjelpeverbet, her eksemplifisert med den koverte HA, den trekkløse (infinitivs-)operatoren ha og fortidsformen hadde:

$$
\begin{aligned}
& \llbracket \mathrm{HA}_{1} \text { (kovert) } / h a_{1} \text { (infinitiv) } \rrbracket=\lambda t \lambda P .\left(\exists t^{\prime} \prec t\right) P\left(t^{\prime}\right) \\
& \llbracket h a_{2} \rrbracket=\lambda t \lambda P . P(t) \\
& \llbracket h a d d e_{1} \rrbracket=\lambda t \lambda P .\left(\exists t^{\prime} \prec t\right) P\left(t^{\prime}\right) \\
& \text { (morfologiske trekk: up eller kombinasjonen up,us) } \\
& \llbracket \text { hadde } e_{2} \rrbracket=\lambda t \lambda P . P(t) \\
& \text { (morfologiske trekk: up eller kombinasjonen up,us) }
\end{aligned}
$$

Variant 1 er den ekte temporale tilbakeskifteren, her behandlet som en ubestemt eksistenskvantor. Vi kan også ha referensiell/bestemt tempus med tilhørende modifisering av variant 1 . Variant 2 er den meningsløse identitetsbetydningen, som selvsagt alltid er knyttet til en overt operator (ha/hadde), da kovert meningsløshet vil være en smule unødvendig.

For språk som engelsk, tysk og fransk kan vi nøye oss med følgende stipulering:

(38) LF-stryking av hjelpeverbet $i$ indo-europeiske språk:

Det temporale hjelpeverbet med trekk-kombinasjonen up, us kan fakultativt strykes på LF (tolkes som identitet) i antesedenten til kontrafaktiske kondisjonaler. 
For norsk (og nederlandsk) har vi sett at regelen i (38), som i seg selv er ganske ad hoc, ikke er tilstrekkelig. Her må det sterkere lut til:

\section{Generell LF-stryking av hjelpeverbet i norsk:}

Det temporale hjelpeverbet kan fakultativt strykes på LF (tolkes som identitet) i kontrafaktiske kondisjonaler.

Hvis slike regler som i (39) var gjennomgående i syntaks-semantikk-grensesnittet, ville det bety slutten for komposisjonalitet og syntaks og semantikk som en teoretisk stringent disiplin. Da ville vi være tilbake til utgangspunktet og kunne kalle inn tellekorpset: lingvistikk kunne reduseres til ren empirisme.

Noen lesere er kanskje fristet av et annet alternativ: Siden vi uansett må anta en abstrakt IRR-operator på LF, kunne man tenke seg et system der den abstrakte IRR-operatoren med skop over hele kondisjonalen sjekker ut selve HJELPEVERBET i antesedenten og konsekventen. Det som gjør dette problematisk, er at ha/hadde er leksikalsk uttrykte operatorer, mens sjekking/lisensiering skjer fra en operator til morfologiske trekk ved for eksempel hadde. Den leksikalske betydningen til ha/hadde forsvinner ikke av seg selv.

Vi kan selvsagt si at bruken av (pluskvam)perfektum i kontrafaktiske kondisjonaler er et sTILISTISK fenomen uten prinsipielle implikasjoner for syntaks og semantikk. Men vi blir ikke stort klokere av slikt, særlig fordi vi som morsmålsbrukere ikke føler at (pluskvam)perfektumkonstruksjonen i nåtidskontekster er stilistisk markert. Det samme gjelder fravær av hjelpeverbet $h a$-i moderne norsk kan ikke dette sies å være en stilistisk markert konstruksjon.

Når det gjelder distribusjonen i korpusdataene, står vi igjen med mønsteret i tabell $2 .{ }^{9}$

TABELL 2: Faktisk bruk i kontrafaktiske matrisesetninger.

\begin{tabular}{llll} 
& NORSK & ENGELSK & FRANSK \\
\hline FRAMTID & $\begin{array}{l}\text { ville bli } \\
\text { ville blitt } \\
\text { ville ha blitt }\end{array}$ & would become & deviendrait \\
\hline \multirow{2}{*}{ NÅTID } & $\begin{array}{l}\text { ville være } \\
\text { ville vært } \\
\text { ville ha vært }\end{array}$ & would be & serait \\
\hline FORTID & $\begin{array}{l}\text { ville vært } \\
\text { ville ha vært }\end{array}$ & would have been & aurait été \\
\hline
\end{tabular}

[9] For framtidsbetydningen i tabell 2 har jeg eksemplifisert med et telisk verb siden vi da får en kovert FUT-operator. 
I mine data er ikke forskjellen på hypotetiske og kontrafaktiske tolkninger særlig tydelig. I hvert fall er det ingen klar korrespondanse mellom disse to tolkningene og henholdsvis formene ville + infinitiv og ville + partisipp, slik hypotesen i tabell 1 la opp til. Forskjellen mellom "hypotetisk" og "kontrafaktisk" nåtids-/ framtidsreferanse, kan i denne artikkelen reduseres til en forskjell mellom teliske og ateliske predikater i kontrafaktiske kontekster uten fortidsforankring. Ved teliske predikater må vi sette inn en kovert FUT på LF - man må gjerne kalle disse konstruksjonene for "hypotetiske", eller "future less vivid" (Iatridou 2000), men terminologien endrer ingenting prinsipielt ved analysen.

Jeg vil avslutte med et par generaliseringer som vanskelig lar seg formalisere. Selv om det ikke er en komposisjonelt motivert strategi, virker det som vi kan få et hint til riktig analyse ved å kaste et blikk på antesedenten. Hvis A uttrykkes gjennom enkel preteritum, vil ville vœrt tilsvare ett lag med fortidsmorfologi og vil i prinsippet kunne byttes ut med formen ville vore. I hvert fall vil den engelske oversettelsen typisk være would be, den tyske wäre og den franske serait. Hvis derimot A inneholder to lag fortid gjennom pluskvamperfektum, er det naturlig å analysere ville vœert som en variant av ville ha vœrt - altså annen kondisjonalis med stryking av ha. Det må innrømmes at det er helt uklart hvorfor vi har denne temporale parallelliteten mellom A og K; men ikke desto mindre finner vi et regelmessig samsvar i indo-europeiske språk mellom morfo-syntaksen i antesedenten og konsekventen.

Vi ender altså opp med å måtte erkjenne at norsk ha-perfektum er tvetydig i kontrafaktiske kondisjonaler: hjelpeverbet kan signalisere relativ fortid (tradisjonell perfektum-betydning) eller det kan være semantisk tomt. Begge tolkningene er dessuten tilgjengelige i konstruksjoner uten overt $h a$, nemlig ved partisippfor-infinitiv. ${ }^{10}$

Heldigvis har denne studien vist at bruken av perfektum er unntaket. De andre morfo-syntaktiske elementene i kontrafaktiske kondisjonaler er komposisjonelle både i norsk og de andre språkene.

\section{T A K K}

Jeg takker Marit Julien og fagfellene for meget gode innspill som har gjort artikkelen bedre enn jeg hadde planlagt. Videre må jeg takke Arnim von Stechow, som ikke direkte har vært involvert i dette arbeidet, men som har gitt meg en litt dypere forståelse av temporalitet i kontrafaktiske kondisjonaler. Hvis jeg ikke kom dypt nok ned i materien denne gang, noe den negative konklusjonen tyder på, er det fullt og helt min egen skyld.

[10] Et klassisk spørsmål i perfektum-litteraturen som ikke er problematisert i denne artikkelen, er knyttet til lokaliseringen av PERF: er den semantiske operatoren i AuxP eller PartP? Jeg har her antatt at perfektumbetydningen kommer med hjelpeverbet i AuxP. 


\section{REFERANSER}

Aasen, Ivar. 1864. Norsk grammatik. Kristiania: Malling.

Eide, Kristin Melum. 2005. Norwegian modals. Berlin: De Gruyter.

Eide, Kristin Melum. 2011. The Ghost of the Old Norse Subjunctive: the Norwegian Subjunctive Participle. Groninger Arbeiten zur germanistischen Linguistik 53(2). 1-28.

Grønn, Atle \& Arnim von Stechow. 2011. The temporal organisation of indicative conditionals. Ms.

Iatridou, Sabine. 2000. The grammatical ingredients of counterfactuality. Linguistic Inquiry 31(2). 231-270.

Ippolito, Michela. 2003. Presuppositions and implicatures in counterfactuals. Natural Language Semantics 11(2). 145-186.

Julien, Marit. 2002. Optional ha in Swedish and Norwegian. Journal of Comparative Germanic Linguistics 5. 67-95.

Julien, Marit. 2003. Dobbelsupinum og irreal modus. Norsk Lingvistisk Tidsskrift 21. $135-161$.

Kratzer, Angelika. 2012. Modals and conditionals: New and revised perspectives, vol. 36. Oxford University Press.

Lewis, David. 1979. Counterfactual dependence and time's arrow. Noûs 13(4). 455-476.

Ogihara, Toshiyuki. 2000. Counterfactuals, temporal adverbs, and association with focus. In Proceedings of SALT, vol. 10, 115-131.

KONTAKTINFORMASJON

Atle Grønn

Institutt for litteratur, områdestudier og europeiske språk

Universitetet i Oslo

Norge

atle.gronn@ilos.uio.no 